\title{
Growth optimization of Saccharomyces cerevisiae and Rhizopus oligosporus during fermentation to produce tempeh with high $\beta$-glucan content
}

\author{
SAMSUL RIZAL", MURHADI, MARIA ERNA KUSTYAWATI, UDIN HASANUDIN \\ Department of Agricultural Product Technology, Faculty of Agriculture, Universitas Lampung. Jl. Soemantri Brojonegoro No. 1, Bandar Lampung \\ 35141, Lampung, Indonesia. Tel.: +62-721-701609, `email: samsul.rizal@fp.unila.ac.id
}

Manuscript received: 10 March 2020. Revision accepted: 20 May 2020.

\begin{abstract}
Rizal S, Murhadi, Kustyawati ME, Hasanudin U. 2020. Growth optimization of Saccharomyces cerevisiae and Rhizopus oligosporus during fermentation to produce tempeh with high $\beta$-glucan content. Biodiversitas 21: 2667-2673. Saccharomyces cerevisiae grows and produces $\beta$-glucan during fermentation in tempeh production. The content of $\beta$-glucan in tempeh is influenced by the growth of $S$. cerevisiae throughout fermentation. The purpose of this study was to determine the effects of different types and concentrations of carbon sources on yeast growth, fungi growth, and $\beta$-glucan content in tempeh inoculated using Rhizopus oligosporus and S. cerevisiae. This study used a Factorial Randomized Complete Block Design (RCBD) with two factors and three replications. The first factor was the types of carbon sources, tapioca and wheat flour; the second factor was the concentrations of carbon source, $0.0 \%, 2.5 \%, 5.0 \%, 7.5 \%$ and $10.0 \%(\mathrm{w} / \mathrm{w})$. Tempeh produced was investigated for yeast number, fungi number, $\beta$-glucan content, and $\mathrm{pH}$ value. The obtained data were tested using Tukey's Honestly Significance Difference (HSD) test. The results showed that the addition of various types and concentrations of carbon source significantly influenced the increase in yeast number, fungi number, $\beta$-glucan content, and $\mathrm{pH}$ in tempeh. The growth of yeast, fungi, and $\beta$-glucan content increased along with the increment of carbon source concentration. The amounts of yeast, fungi, and $\beta$-glucans in tempeh added with tapioca were higher compared to tempeh with wheat flour. The addition of $10 \%$ tapioca produced the highest amount of yeast with $9.505 \mathrm{Log} C F U / \mathrm{g}$ and the highest $\beta$-glucan content with $0.707 \%$ (w/w).
\end{abstract}

Keywords: $\beta$-glucan, carbon source, Rhizopus oligosporus, Saccharomyces cerevisiae, tempeh

\section{INTRODUCTION}

Tempeh is a popular traditional food from Indonesia made of soybeans. It is beneficial as a source of fiber for human health (Soka et al. 2014). Tempeh is produced from fermented boiled soybeans through the enzymatic activity of Rhizopus oligosporus (Kustyawati et al. 2016). Rhizopus oligosporus is a fungus that plays a major role in producing tempeh. This fungus can maintain most of nutrients contained in soybeans and enhance the digestibility of protein and several types of vitamin B. According to Mo et al. (2013), Vitamin B12 and folate of tempeh were influenced by microbial activity during fermentation, whereas isoflavone aglycone content of tempeh was determined by bean variety.

At first, fungus was the only microbe that had the most role in tempeh fermentation. However, based on several studies, there was bacteria and yeast involvement in tempeh fermentation. According to Pangastuti et al. (2019), several types of microbes had been found in tempeh and during the immersion process of soybeans. The presence of yeast in this fermentation showed that yeast could grow and interact with other microflora and was thought to have a role in improving the flavor and nutrient quality of tempeh (Kustyawati 2009). One type of yeast found in tempeh fermentation was Saccharomyces cerevisiae (Kustyawati et al. 2016), a known source of $\beta$-glucan (Many and Vizy 2014; Pengkumsri et al. 2017). $\beta$-glucan is a polysaccharide compound that has various biological activities: as a biological response modifier (Corno et al. 2020); as an anti-infectious agent against microorganisms including bacteria, fungi, viruses, and parasites (Hetland et al. 2013); as an anti-cytotoxic, antimutagenic, and anti-tumorigenic (Widyastuti et al. 2011); and as an enhancer of anticancer immunity responses (Vannucci et al. 2013). Research by Meena et al. (2013) also showed that $\beta$-glucan imparted immunity against various fish pathogens.

In this study, S. cerevisiae was intentionally added to the tempeh fermentation process to produce tempeh that contained $\beta$-glucan. Based on the research by Rizal et al. (2018), tempeh added with $3 \%$ S. cerevisiae in its fermentation produced the highest $\beta$-glucan content which was $0.076 \%$. Meanwhile, Pratiwi (2018) explained that adding a mixed inoculum of $R$. oligosporus and $S$. cerevisiae in 40 hours of fermentation resulted in the highest $\beta$-glucan content in tempeh with $0.578 \%(\mathrm{w} / \mathrm{w})$. However, the amount of $\beta$-glucan in tempeh produced from the study was considered to still be low because the growth of $S$. cerevisiae during fermentation was not optimal. According to Rizal (2018b), the highest amount of yeast in tempeh inoculated with $R$. oligosporus and $S$. cerevisiae was $1.31 \times 10^{8} \mathrm{CFU} / \mathrm{g}$. The amount of yeast in tempeh may still be increased if the growth substrate contains enough nutrients for its growth. Yeast growth requires a high carbon source, whereas tempeh only contains $12.1 \%$ 
carbohydrates (Cahyadi 2006). Therefore, to optimize the growth of $S$. cerevisiae during fermentation, it is necessary to add substrates that contain nutrients needed for the growth of $S$. cerevisiae, which is mainly carbon.

Tapioca and wheat flour are known to contain high carbohydrates. The carbon content in tapioca and wheat flour is thought to meet the nutritional needs for the growth of $S$. cerevisiae and $R$. oligosporus during tempeh fermentation. Therefore, the addition of tapioca and wheat flour to tempeh fermentation is expected to optimize the growth of $S$. cerevisiae and $R$. oligosporus which will produce $\beta$-glucans. The purpose of this study was to determine the type and concentration of carbon sources that increased the growth of yeast and fungi most optimally and produced tempeh with the highest $\beta$-glucan content.

\section{MATERIALS AND METHODS}

\section{Materials}

The materials used in this study were pure culture of Rhizopus oligosporus FNCC 6010 and Saccharomyces cerevisiae FNCC 3012 obtained from the Inter-University Center for Food and Nutrition, UGM Yogyakarta; imported soybeans with the trademark Soybean USA No. 1 obtained from Gunung Sulah in Bandar Lampung; wheat flour; tapioca; Oxoid Potato Dextrose Agar (PDA); Oxoid Malt Extract Agar (MEA); purified water; chloramphenicol; $\mathrm{NaOH} 0.7 \mathrm{~N}$; phosphate buffer $\mathrm{pH} 4$ and $\mathrm{pH} 7 ; \mathrm{Pb}$ $\left(\mathrm{C}_{2} \mathrm{H}_{3} \mathrm{O}_{2}\right)_{2} ; \mathrm{H}_{2} \mathrm{SO}_{4} ; \mathrm{C}_{6} \mathrm{H}_{5} \mathrm{OH} ; \mathrm{CH}_{3} \mathrm{COOH} ; \mathrm{Na}_{2} \mathrm{C}_{2} \mathrm{O}_{4} ; \mathrm{NaCl}$; $70 \%$ alcohol; and aluminum foil.

\section{Methods}

This study used a Randomized Complete Block Design with two factors and three replications. The first factor was the types of carbon sources, tapioca and wheat flour. The second factor was carbon source concentrations, $0.0 \%$, $2.5 \%, 5.0 \%, 7.5 \%$, and $10.0 \%$ (w/w). Boiled soybeans were inoculated with pure $R$. oligosporus and $S$. cerevisiae inoculum then added with different carbon sources of different prescribed concentrations. Observation was made to record the number of fungi and yeast, $\mathrm{pH}$ value, and $\beta$ glucan content after a 36-hour fermentation at room temperature. Data were analyzed by ANOVA (analysis of variance) and tested further using Tukey's Honestly Significant Difference (HSD) test at the 5\% level.

\section{Preparation of $S$. cerevisiae culture}

Isolated $S$. cerevisiae was cultured into sterile Malt Extract Agar (MEA) medium using a sterilized inoculating needle with a scratchplate, then incubated for 24 to 48 hours at $28^{\circ} \mathrm{C}$ to form colonies. The colonies were harvested by adding $10 \mathrm{~mL}$ of distilled water into the plate disk. Saccharomyces cerevisiae cells were harvested and poured into a $50 \mathrm{~mL}$ centrifuge tube. The tube was weighed and spun at $3000 \mathrm{rpm}$ for 10 minutes to obtain a separate solid from the supernatant. The supernatant was discarded, and the remaining solids were diluted with 25 to $30 \mathrm{~mL}$ of distilled water. The $S$. cerevisiae cells were transferred into a test tube containing $9 \mathrm{~mL}$ of physiological saline solution, and then homogenized using a vortex. The number of $S$. cerevisiae cells was calculated using a hemocytometer. The required concentration was $10^{7}$ cells/mL (Kustyawati et al. 2009).

\section{Preparation of Rhizopus oligosporus culture}

Rhizopus oligosporus from tilted agar was cultured onto a sterile medium of Potato Dextrose Agar (PDA) using a sterilized inoculating needle and a scratchplate, and then incubated for five to seven days at $30^{\circ} \mathrm{C}$ to $35^{\circ} \mathrm{C}$ to obtain pure colonies, harvested in the same way as the $S$. cerevisiae. The required concentration $\left(10^{5}\right.$ cells $\left./ \mathrm{mL}\right)$ was 100 times less than that of $S$. cerevisiae (Kustyawati et al. 2009).

\section{Tempeh production}

The procedure of tempeh processing followed by Kustyawati et al. (2009). A total of $100 \mathrm{~g}$ of soybeans were soaked at room temperature overnight. Afterward, the soybean husks were removed manually. Soybeans were then boiled with a 1:3 ratio of soybeans to water for 30 minutes, drained, and aerated before they were ready to be inoculated. The inoculation stage was carried out by mixing every $100 \mathrm{~g}$ of boiled soybeans with $1 \mathrm{~mL}$ of $10^{7}$ spores $/ \mathrm{mL} R$. oligosporus $+1 \mathrm{~mL}$ of $10^{7}$ cell $/ \mathrm{mL} S$. cerevisiae suspension. Specific concentration of flour was then added to the microorganism-inoculated soybeans. Finally, the mixture was packaged with plastic with aeration holes and incubated for 36 hours at room temperature.

\section{Enumeration of microorganisms}

Culturing was done on Potato Dextrose Agar (PDA) for fungi and on Malt Extract Agar (MEA) for yeast. Tempeh was sampled and diluted following the method of Kustyawati et al. (2009). Ten grams of sample and $90 \mathrm{~mL}$ of peptone water were homogenized with a stomacher paddle blender for five minutes, and then diluted into the concentration series. One $\mathrm{mL}$ of each dilution was planted with the appropriate surface plate calculation method on the media. Incubation happened for 24 to 48 hours at $32^{\circ} \mathrm{C}$ to grow fungi and at $30^{\circ} \mathrm{C}$ to grow yeast.

\section{Analysis of $\beta$-glucan}

The $\beta$-glucan production was determined every eight hours during fermentation, following Kusmiati et al. (2007). One gram of sample and $30 \mathrm{~mL}$ of $\mathrm{NaOH} 0.7 \mathrm{~N}$ were hydrolyzed for six hours at $75^{\circ} \mathrm{C}$ and then centrifuged at $10,000 \mathrm{rpm}$ at $25^{\circ} \mathrm{C}$ for 30 minutes. The supernatant was removed, and the residue was washed with $30 \mathrm{ml}$ of $0.5 \mathrm{M}$ acetic acid solution and centrifuged again at 10,000 rpm and $25^{\circ} \mathrm{C}$ for 30 minutes. The supernatant was removed again and then washed with acetic acid three times. The obtained residue was then washed twice with $20 \mathrm{~mL}$ of water and centrifuged at 5,000 rpm for 10 minutes.

The residue and $20 \mathrm{~mL}$ of ethanol were centrifuged at $5,000 \mathrm{rpm}$ for 10 minutes, resulting in wet $\beta$-glucan (crude wet $\beta$-glucan). This biomass was dehydrated using oven at $45^{\circ} \mathrm{C}$ for 24 hours and weighed, resulting in crude dry $\beta$ glucan. The dry residue with $4 \mathrm{~mL}$ of $1 \mathrm{M} \mathrm{NaOH}$ was left 
for one hour. The sample was then diluted with $10 \mathrm{~mL}$ of purified water and shaken with an orbital shaker. After that, the sample was added with $2 \mathrm{~mL}$ of $\mathrm{Pb}$-Acetate and left to stand for 30 minutes. Finally, one gram of sodium oxalate cleared the solution. Two $\mathrm{mL}$ of the solution with $0.5 \mathrm{~mL}$ of phenol $5 \%$ and $2.5 \mathrm{~mL}$ of sulfuric acid $5 \mathrm{~N}$ was tested using a sugar-free content spectrophotometer with a wavelength of $490 \mathrm{~A}$.

\section{RESULTS AND DISCUSSION}

\section{Growth of yeast}

Saccharomyces cerevisiae added in tempeh fermentation grew together with $R$. oligosporus to form tempeh. Figure 1 shows that carbon source concentration influenced the number of $S$. cerevisiae cells in tempeh. The higher the concentration of carbon source added to the tempeh fermentation process, the higher the number of $S$. cerevisiae cells in tempeh. Tempeh with $10 \%$ tapioca contained the highest number of $S$. cerevisiae cells with 3.9 x $10^{9} \mathrm{CFU} / \mathrm{g}$, while the lowest number of $S$. cerevisiae cells was found in $0 \%$ wheat flour with $1.0 \times 10^{8} \mathrm{CFU} / \mathrm{g}$. Figure 1 displays the growth of $S$. cerevisiae in tempeh with different types and concentrations of carbon sources.

Based on Figure 1, the highest number of yeast cells was found in tempeh produced by adding $10 \%$ tapioca with up to $9.50 \log \mathrm{CFU} / \mathrm{g}$ of $S$. cerevisiae. Overall, these results showed an increase in the number of yeast cells along with the increase of concentration of both carbon sources. These results proved that nutrients contained in added carbon source could be utilized by yeast cells to support their growth. Wheat contains $74.48 \%$ carbohydrates while tapioca contains 86.9\% carbohydrates (USDA 2014). According to Saini et al. (2017), S. cerevisiae was a potential amylase-producing organism. Therefore, $S$ cerevisiae could break down carbohydrates in both types of carbon sources into simpler compounds. Melliawati et al. (2006) stated that amylolytic microorganisms, one of which was $S$. cerevisiae, could thrive in solid media containing $2 \%$ sago starch as a source of carbon and energy. Besides being able to grow well, these microorganisms could also break down starch into simpler compounds. Additionally, research results from Kustyawati et al. (2013) showed that the number of $S$. cerevisiae increased from $6.85 \mathrm{Log}$ $\mathrm{CFU} / \mathrm{mL}$ to $7.63 \mathrm{Log} \mathrm{CFU} / \mathrm{mL}$ when producing tempeh with tapioca through fermentation by $S$. cerevisiae for 48 hours.

Statistical analysis showed that adding different carbon source types and concentrations during formation of tempeh had a significant effect on the number of $S$. cerevisiae cells with an average value ranging from 8.01 $\mathrm{Log} \mathrm{CFU} / \mathrm{g}$ to $9.50 \mathrm{Log} \mathrm{CFU} / \mathrm{g}$. Further investigation through HSD test regarding the effect of adding different types and concentrations of carbon source on the number of yeast cells is shown in Table 1 .

Based on Table 1, the number of yeast (S. cerevisiae) cells in tempeh containing $10.0 \%$ tapioca was not significantly different from that with $10 \%$ wheat flour, but it was significantly different from those with other concentrations. The highest number was obtained in tempeh by adding $10 \%$ tapioca producing yeast cells up to 9.50 ( $\pm 0.12 \mathrm{SD}) \mathrm{Log}$ CFU/g. The number of yeast cells with the addition of the lowest wheat flour concentration (2.5\%) was $8.18( \pm 0.08)$ Log CFU/g, thus still higher than those without added carbon source.

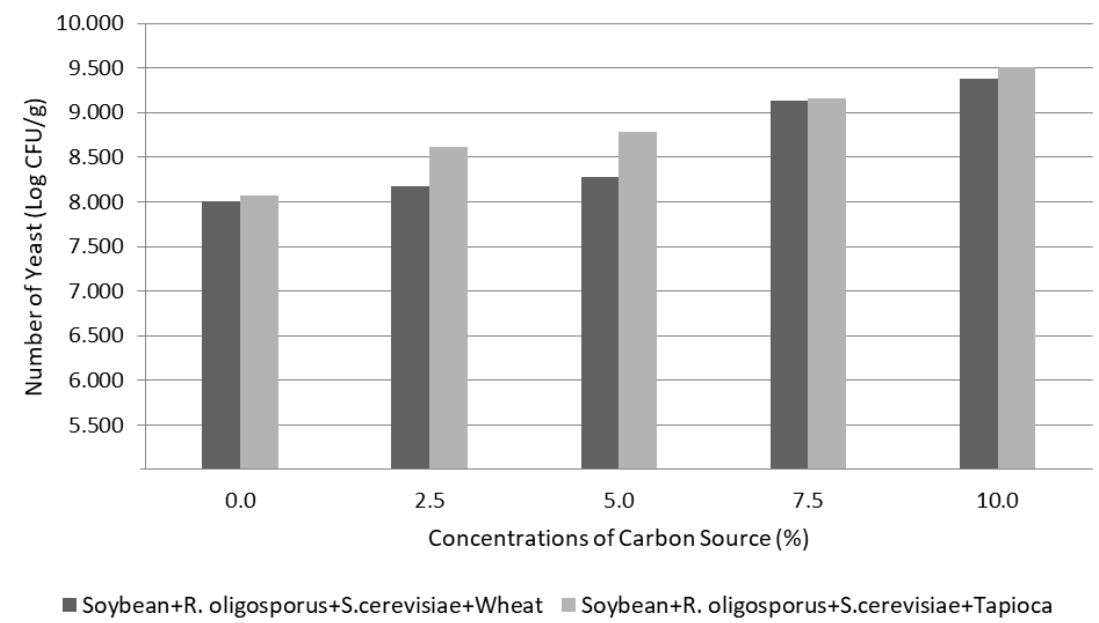

Figure 1. Growth of yeast cell in tempeh inoculated with Rhizopus oligosporus and Saccharomyces cerevisiae with the addition of different types and concentrations of carbon source 


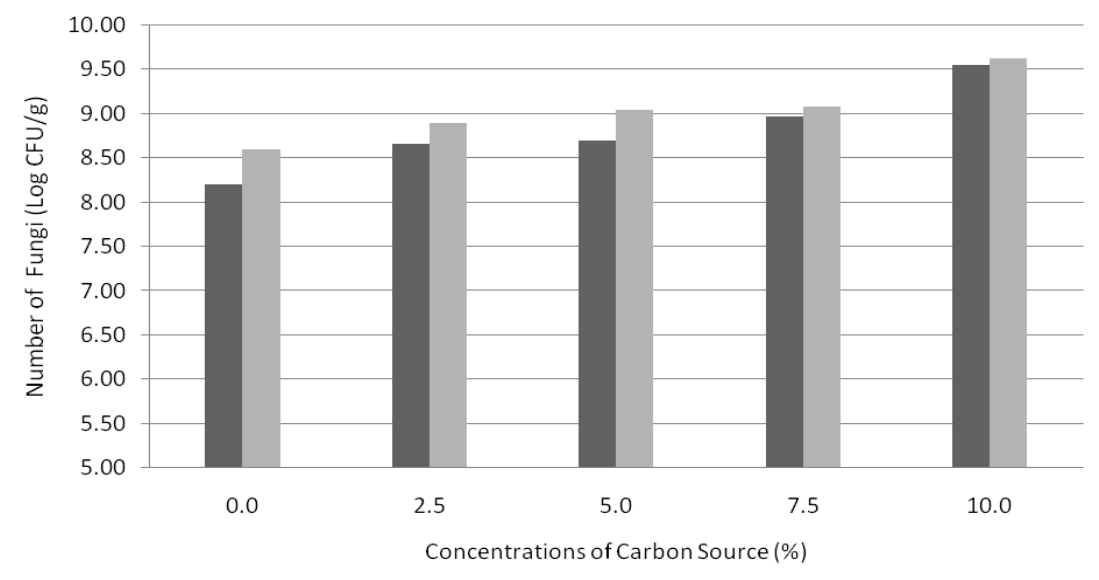

m Soybean+R. oligosporus+S.cerevisiae+Wheat $n$ Soybean+R. oligosporus+S.cerevisiae+Tapioca

Figure 2. Graph of the growth of fungi cells in tempeh inoculated with pure cultures of Rhizopus oligosporus and Saccharomyces cerevisiae with the addition of different types and concentrations of carbon source

According to Walker and Stewart (2016), most $S$. cerevisiae strains could grow if they were supplied with glucose, inorganic ions, ammonium salts, and a few other growth factors. Macronutrients need to be supplied at millimolar concentrations, and these comprise of sources of carbon (i.e., sugars), oxygen, free amino nitrogen (amino acids, small peptides, and ammonium salts), phosphorus, sulfur, potassium, and magnesium. Suprihatin (2010) stated that the amount of nutrients in fermentation media might affect the number of cells produced. Since there was no significant difference in the number of yeast cells in tempeh with $10 \%$ tapioca and $10 \%$ wheat flour, it could be assumed that both carbon source types contained similar amount of those necessary nutrients. However, according to Rizal (data not shown), in the absence of fungi, $S$. cerevisiae could still grow during fermentation of soybeans inoculated with $S$. cerevisiae even though tempeh was not formed.

\section{Growth of fungi}

Growth of $R$. oligosporus increased with increasing concentrations of added carbon sources. The result showed that the highest number of $R$. oligosporus cells was obtained in tempeh produced by adding $10 \%$ tapioca with total cells up to $5.0 \times 10^{9} \mathrm{CFU} / \mathrm{g}$, while the lowest number of $R$. oligosporus cells was found in tempeh produced by $0 \%$ wheat flour with $2.2 \times 10^{8} \mathrm{CFU} / \mathrm{g}$. Statistical analysis proved that the addition of carbon source with different concentrations had a significant effect on the number of $R$. oligosporus cells. The addition of carbon source was intended to support the growth of yeast during fermentation, but the nutrient in carbon source was also used by fungi during fermentation. As carbon source concentration increased, the number of fungi cells increased as well. Overall, tapioca yields higher amount of fungi than wheat flour in any concentration. The graph showing the growth of fungi cells in tempeh inoculated with culture mixture of $R$. oligosporus and S. cerevisiae with the addition of different types and concentrations of carbon source is shown in Figure 2.
Table 1. The result of HSD analysis on the effect of adding different types and concentrations of carbon source on the number of $S$. cerevisiae in tempeh

\begin{tabular}{lc}
\hline \multicolumn{1}{c}{ Treatments } & $\begin{array}{c}\text { Number of } \text { S. cerevisiae } \pm \text { SD } \\
(\text { Log CFU/g) }\end{array}$ \\
\hline Tapioca 10.0\% & $9.50 \pm 0.12^{\mathrm{a}}$ \\
Wheat $10.0 \%$ & $9.38 \pm 0.07^{\mathrm{ab}}$ \\
Tapioca $7.5 \%$ & $9.16 \pm 0.04^{\mathrm{bc}}$ \\
Wheat $7.5 \%$ & $9.13 \pm 0.12^{\mathrm{c}}$ \\
Tapioca $5.0 \%$ & $8.78 \pm 0.10^{\mathrm{d}}$ \\
Tapioca $2.5 \%$ & $8.62 \pm 0.07^{\mathrm{d}}$ \\
Wheat $5.0 \%$ & $8.27 \pm 0.10^{\mathrm{e}}$ \\
Wheat $2.5 \%$ & $8.18 \pm 0.08^{\mathrm{ef}}$ \\
Tapioca $0.0 \%$ & $8.08 \pm 0.03^{\mathrm{ef}}$ \\
Wheat $0.0 \%$ & $8.01 \pm 0.05^{\mathrm{f}}$ \\
\hline
\end{tabular}

Note: Data presented in means \pm SD. The mean value followed by the same letter indicates no significant difference in the 5\% HSD test. $(\alpha=0.231)$

Table 2. The results of HSD Test on the effect of adding different types of carbon source at different concentrations on the amount of Rhizopus oligosporus cells in tempeh

\begin{tabular}{lc}
\hline \multicolumn{1}{c}{ Treatments } & $\begin{array}{c}\text { Number of } R \text {. oligosporus } \pm \text { SD } \\
(\text { Log CFU/g) }\end{array}$ \\
\hline Tapioca $10.0 \%$ & $9.63 \pm 0.31^{\mathrm{a}}$ \\
Wheat $10.0 \%$ & $9.55 \pm 0.19^{\mathrm{ab}}$ \\
Tapioca $7.5 \%$ & $9.08 \pm 0.09^{\mathrm{abc}}$ \\
Tapioca $5.0 \%$ & $9.04 \pm 0.12^{\mathrm{abc}}$ \\
Wheat $7.5 \%$ & $8.96 \pm 0.02^{\mathrm{bc}}$ \\
Tapioca $2.5 \%$ & $8.89 \pm 0.11^{\mathrm{c}}$ \\
Wheat $5.0 \%$ & $8.69 \pm 0.10^{\mathrm{cd}}$ \\
Wheat $2.5 \%$ & $8.66 \pm 0.09^{\mathrm{cd}}$ \\
Tapioca $0.0 \%$ & $8.59 \pm 0.31^{\mathrm{cd}}$ \\
Wheat $0.0 \%$ & $8.20 \pm 0.45^{\mathrm{d}}$ \\
\hline
\end{tabular}

Note: Data presented in means \pm SD. The mean value followed by the same letter indicates no significant difference in the 5\% HSD test. $(\alpha=0.63)$ 
Fungi have an important role in the processing of tempeh because they can retain most of the nutrients contained in soybean seeds and increase the digestibility of proteins and certain types of vitamin B. Rhizopus oligosporus produces proteases that can break down proteins into peptides, amylase enzymes that can break down starch into sugars, and lipase enzymes that can digest fats (Kobayasi et al. 1992). Similarly, Setiarto, et al. (2016) stated that during the fermentation process, $R$. oligosporus produced extracellular enzymes such as amylase and protease that degraded starch and protein contained in sorghum seeds into simple sugars and amino acids. Wang et al. (2012) reported that a decrease in carbohydrate content occurred in small amount in tempeh produced by a mixture of soybeans and wheat inoculated with $R$. oligosporus inoculum. The decrease in carbohydrates was caused by $R$. oligosporus using carbohydrates as a source of carbon for its growth. Research by Widiantara (2012) showed that there was a significant decrease in starch content in cassava fermented by $R$. oligosporus. This confirmed that $R$. oligosporus could break down starch into simpler compounds because these fungi contained the alpha-amylase enzyme (Kanti 2016).

Statistical analysis showed that the number of fungi cells was influenced by several carbon source types and concentrations as well as the interaction between the two. Further test results depicted that the types and concentrations of carbon sources had a significant effect on the number of $R$. oligosporus cells at the 5\% level. HSD test results are shown in Table 2.

Based on Table 2, the number of $R$. oligosporus cells on tempeh with $10 \%$ tapioca was not significantly different from those with $10.0 \%$ wheat flour, $7.5 \%$ tapioca, and $5.0 \%$ tapioca; but it was significantly different from those with $7.5 \%$ wheat flour, $2.5 \%$ tapioca, $5.0 \%$ wheat flour, $2.5 \%$ wheat flour, $0.0 \%$ tapioca, and $0.0 \%$ wheat flour. The number of $R$. oligosporus cells on tempeh with $10.0 \%$ wheat flour was not significantly different from $7.5 \%$ tapioca, $5.0 \%$ tapioca, and $7.5 \%$ tapioca and wheat flour. These results were close to the research conducted by Aptesia et al. (2013) and they proved that tapioca could act as a nutrient substrate for growing $R$. oligosporus because it had high carbohydrate content of $84.2 \%$, consisting of $17-23 \%$ amylose and $76-83 \%$ amylopectin. Research by Hermiati et al. (2011) also explained that tapioca had $96.06 \%$ starch and $20.47 \%$ amylose. The carbohydrate content in tapioca and wheat flour will be overhauled by $R$. oligosporus because it contains amylase enzyme. In aerobic conditions, $R$. oligosporus produces a lot of extracellular amylase enzymes (Crueger and Crueger 1984). The enzyme is produced to break down complex compounds into simpler compounds, so that they can be absorbed by cells and used for growth.

\section{$\beta$-glucan content}

Results showed an increase in $\beta$-glucan content along with the increase of carbon source concentration added in tempeh fermentation. The highest $\beta$-glucan content was found in $10 \%$ tapioca with $0.707 \%$ and the lowest with $0.12 \%(\mathrm{w} / \mathrm{w})$ in $0 \%$ both carbon sources. The results indicated that the addition of carbon source during fermentation influenced increasing the content of $\beta$-glucan of tempeh (Table 3).

Table 3. The amount of $\beta$-glucan content in tempeh with the addition of different carbon source types at different concentrations

\begin{tabular}{|c|c|c|}
\hline \multirow{2}{*}{$\begin{array}{l}\text { Carbon source } \\
\text { concentrations } \\
(\%)\end{array}$} & \multicolumn{2}{|c|}{$\begin{array}{l}\% \beta \text {-glucan }(w / w) \pm S D \text { in tempeh at } \\
\text { different types of carbon source }\end{array}$} \\
\hline & Wheat flour & Tapioca \\
\hline 0.0 & $0.118 \pm 0.010$ & $0.145 \pm 0.006$ \\
\hline 2.5 & $0.253 \pm 0.010$ & $0.231 \pm 0.002$ \\
\hline 5.0 & $0.288 \pm 0.014$ & $0.441 \pm 0.026$ \\
\hline 7.5 & $0.445 \pm 0.018$ & $0.487 \pm 0.007$ \\
\hline 10.0 & $0.676 \pm 0.004$ & $0.707 \pm 0.029$ \\
\hline
\end{tabular}

Note: Data presented in means \pm SD

Table 4. Results of HSD test on the effect of adding different types and concentrations of carbon source on the amount of $\beta$ glucan in tempeh

\begin{tabular}{ll}
\hline Treatments & \% $\beta$-glucan $(\mathbf{w} / \mathbf{w}) \pm$ SD \\
\hline Tapioca $10.0 \%$ & $0.707 \pm 0.029^{\mathrm{a}}$ \\
Wheat $10.0 \%$ & $0.676 \pm 0.004^{\mathrm{a}}$ \\
Tapioca $7.5 \%$ & $0.487 \pm 0.007^{\mathrm{b}}$ \\
Wheat $7.5 \%$ & $0.45 \pm 0.018^{\mathrm{b}}$ \\
Tapioca $5.0 \%$ & $0.441 \pm 0.026^{\mathrm{b}}$ \\
Wheat $5.0 \%$ & $0.288 \pm 0.014^{\mathrm{c}}$ \\
Wheat $2.5 \%$ & $0.253 \pm 0.010^{\mathrm{cd}}$ \\
Tapioca $2.5 \%$ & $0.231 \pm 0.002^{\mathrm{d}}$ \\
Tapioca $0.0 \%$ & $0.155 \pm 0.006^{\mathrm{e}}$ \\
Wheat $0.0 \%$ & $0.118 \pm 0.010^{\mathrm{e}}$ \\
\hline
\end{tabular}

Note: Data presented in means \pm SD. The mean value followed by the same letter indicates no significant difference in the 5\% HSD test. $(\alpha=0.046)$

Table 5. The results of HSD Test on the effect of adding different types of carbon source at different concentrations toward $\mathrm{pH}$ value in tempeh.

\begin{tabular}{ll}
\hline Treatments & pH value \pm SD \\
\hline Tapioca $0.0 \%$ & $6.93 \pm 0.03^{\mathrm{a}}$ \\
Wheat $2.5 \%$ & $6.87 \pm 0.05^{\mathrm{ab}}$ \\
Wheat $0.0 \%$ & $6.83 \pm 0.05^{\mathrm{ab}}$ \\
Wheat $10.0 \%$ & $6.78 \pm 0.08^{\mathrm{abc}}$ \\
Wheat $5.0 \%$ & $6.77 \pm 0.02^{\mathrm{abc}}$ \\
Wheat $7.5 \%$ & $6.76 \pm 0.11^{\mathrm{bc}}$ \\
Tapioca $5.0 \%$ & $6.63 \pm 0.03^{\mathrm{cd}}$ \\
Tapioca $7.5 \%$ & $6.56 \pm 0.07^{\mathrm{d}}$ \\
Tapioca $2.5 \%$ & $6.52 \pm 0.07^{\mathrm{d}}$ \\
Tapioca $10.0 \%$ & $6.48 \pm 0.03^{\mathrm{d}}$ \\
\hline
\end{tabular}

Note: Data presented in means \pm SD. The average value followed by the same letter shows no difference in the 5\% HSD test. $(\alpha=$ $0.164)$ 
The increase in the $\beta$-glucan content in tempeh is caused by an increase in the amount of $S$. cerevisiae and $R$. oligosporus. As shown by Figures 1 and 2, increasing the concentration of carbon sources can increase the number of fungus and yeast cells. Increasing the number of fungus and yeast cells will automatically increase the $\beta$-glucan content in tempeh because $\beta$-glucan are found in the cell walls of both microbes. In previously published researches, Naruemon et al. (2013) stated that the cell membrane of $S$. cerevisiae contains $\beta(1,3)$-glucan and $\beta(1,6)$-glucan; Kusmiati et al. (2007) reported that the most optimal increment in $\beta$-glucan weights was obtained from the addition of $6 \%$ and $8 \%$ molasses, which resulted in $\beta$ glucan levels of 53.07 and $61.79 \%$; and Thontowi et al. (2007) stated that the $\beta$-glucan content of $S$. cerevisiae in cultures with $\mathrm{N}$ peptone sources tended to increase within fermentation process and was relatively constant at the end of fermentation, with $\beta$-glucan levels at the end of fermentation of $933.33 \mu \mathrm{g} / \mathrm{L}$.

Statistical analysis showed that carbon source types and concentrations significantly affected $\beta$-glucan content in tempeh with an interaction between the two. HSD test 5\% level analysis results are presented in Table 4. Table 4 shows that $\beta$-glucan content in tempeh with $10 \%$ tapioca is not significantly different from the $10 \%$ wheat flour but it is significantly different from other concentrations. The content of $\beta$-glucan with the addition of either $10 \%$ tapioca or $10 \%$ wheat flour is higher than those with other wheat and tapioca concentrations. The highest $\beta$-glucan content was found in tempeh added with tapioca at $10 \%$ concentration.

$\beta$-glucan can be obtained by extracting $S$. cerevisiae cell membranes through base extraction. In this study, extraction was carried out through base extraction using $\mathrm{NaOH}$ which was based on its solubility in alkaline solutions (Lee 2001). The difference in $\beta$-glucan content produced in tempeh was caused by varying number of nutrients contained in different carbon sources at different concentrations, which affected the number of $S$. cerevisiae cells. $\beta$-glucan production increased along with the number of $S$. cerevisiae cells (Kusmiati et al. 2007). According to Cempaka and Aryantha (2014), formation of $\beta$-glucan increased along with the growth of the cell. The highest $\beta$ glucan content in tempeh in this study, $0.707 \%(\mathrm{w} / \mathrm{w})$, was higher than that from a research conducted by Rizal et al. (2018) through the addition of $3 \%$ S. cerevisiae with $0.076 \%$ and by Pratiwi (2018) through the addition of a mixture of $R$. oligosporus and $S$. cerevisiae at 40 hours fermentation with $0.578 \%(\mathrm{w} / \mathrm{w})$. However, it was lower than the research conducted by Shokri et al. (2008) with $27.5 \%$ and Varelas et al. (2016) with $40 \%$. This significant difference might be caused by the different isolation processes of $\beta$-glucan where generally, $\beta$-glucan was obtained through direct isolation from $S$. cerevisiae cell membranes, whereas in study of Rizal et al. (2018) and Pratiwi (2018), $\beta$-glucan was obtained from tempeh flour extraction.

\section{Value of pH}

Statistical analysis showed that the addition of different carbon sources at different concentrations had a significant influence on the $\mathrm{pH}$ value in tempeh. The result of $\mathrm{pH}$ measurement proved that tempeh with no tapioca $(0 \%)$ had the highest $\mathrm{pH}$ value (6.9) while the lowest $\mathrm{pH}$ value was 6.4 at the mixture of $10 \%$ tapioca. Test results of $\mathrm{pH}$ value in tempeh are presented in Table 5.

Degree of acidity $(\mathrm{pH})$ is an important factor affecting the tempeh fermentation. Azizah et al. (2012) explained that the $\mathrm{pH}$ value is influenced by the product of the fermentation process and there was a correlation between fungal growth and the rise of $\mathrm{pH}$ value. Kustyawati (2009) stated that during fermentation, there were to be no overhaul compounds that produced $\mathrm{H}$ to achieve non-acidic tempeh. Generally, tempeh increased in $\mathrm{pH}$ during the fermentation process (Handoyo and Morita 2006). As long as there was growth of fungi in the fermentation of soybean, the $\mathrm{pH}$ of medium change greatly (Handoyo and Morita 2006) due to water-soluble organic acids were produced from proteins (Sparringa and Owens 1999) and oligosaccharides (Rehms and Barz1995). As reported by Suprihatin (2010), the proteolytic activity of $R$. oligosporus in which protein degradation occurred caused an increase in concentration of dissolved nitrogen in tempeh, thus raising the $\mathrm{pH}$ value of tempeh. Fungi will actively hydrolyze proteins during tempeh fermentation. However, in this study, tempeh decreased in $\mathrm{pH}$ with increasing concentrations of carbon source used. During tempeh fermentation, carbohydrates in tapioca or wheat flour added to the fermentation process were degraded by the activity of enzymes produced by $R$. oligosporus and $S$. cerevisiae into simpler compounds such as disaccharides and monosaccharides. Cempaka and Aryantha (2014) stated that the decrease in $\mathrm{pH}$ of the medium during fermentation was probably caused by the formation of primary metabolites such as organic acids by $S$. cerevisiae. Finally, the formation of organic acids would reduce the $\mathrm{pH}$ value of the medium.

In conclusion, the addition of different types of carbon sources, both tapioca and wheat flour, with different concentrations in tempeh fermentation significantly affects the growth of yeast, fungi, and $\beta$-glucan content. Adding $10 \%$ tapioca $(\mathrm{w} / \mathrm{w})$ in tempeh fermentation resulted in the highest amount of yeast with $9.505 \mathrm{log} \mathrm{CFU} / \mathrm{g}$ and the highest content of $\beta$-glucan with $0.707 \%$ (w/w), whereas the addition of 10 wheat flour only produced $0.676 \%(\mathrm{w} / \mathrm{w})$ $\beta$-glucan content.

\section{ACKNOWLEDGEMENTS}

We would like to profoundly show our gratitude to Rafa Zahrah, an alumnus of the Department of Agricultural Product Technology, Faculty of Agriculture, University of Lampung, Indonesia. We would also like to give our thanks to the Integrated Laboratory of University of Lampung, as well as Research and Community Service Institute of University of Lampung, Indonesia for their contribution to this study. 


\section{REFERENCES}

Aptesia LT, Suharyono, Rasyid HA. 2013. The use of Lactobacilus casei and tapioca to slow down soy tempeh deterioration. Jurnal Teknologi Industri dan Hasil Pertanian 18 (2): 175-184. [Indonesian]

Azizah N, Al-Baarri AN, Mulyani S. 2012. Effect of fermentation time on alcohol content, $\mathrm{pH}$, and gas production on the bioethanol fermentation process of whey with pineapple skin substitution. Jurnal Aplikasi Teknologi Pangan 1 (2): 72-77. [Indonesian]

Cahyadi W. 2006. Kedelai Khasiat dan Teknologi. Bumi Aksara, Bandung. [Indonesian]

Cempaka L, Aryantha INP. 2015. Effect of Glucose Concentration on the Production of $\beta$-glucan by Saccharomyces cerevisiae. 2nd AsiaAustralia Dairy Goat Conference, 26-27 April 2014, Bogor, Indonesia. [Indonesian]

Corno MD, Gessani S, Conti L. 2020. Shaping the innate immune response by dietary glucans: Any role in the control of cancer? Cancers (Basel) 12 (1): 155. DOI: 10.3390/cancers12010155.

Crueger W, Crueger A. 1984. Biotechnology: A Textbook of Industrial Microbiology. Sinauer Tech, Inc, Madison.

Handoyo T, Morita N. 2016. Structural and Functional Properties of Fermented Soybean (Tempeh) by Using Rhizopus oligosporus. Intl J Food Prop 9 (2): 347-355.

Hermiati E, Azuma J, Mangunwidjaja D, Sunarti T, Suparno O, Prasetya B. 2011. Hydrolysis of carbohydrates in cassava pulp and tapioca flour under microwave irradiation. Indones J Chem 11 (3): 238-245.

Hetland G, Johnson E, Eide DM, Grinde B, Samuelsen ABC, Wiker HG 2013. Antimicrobial effects of $\beta$-glucan and pectin and of the Agaricus blazei based Mushroom Extract, AndoSan T. Examples of Mouse Models for Pneumococcal, Fecal Bacterial, and Mycobacterial Infections. Microbial Pathogens and Strategies for Combating Them. Science, Technology and Education (A. Méndez-Vilas, Ed.). Formatex. Pp: 889-898.

Kanti A. 2016. Effect of Nitrogen Addition on the $\alpha$-amylase production by Aspergillus niger, Rhizopus oligosporus and Neurospora crassa in media contained sargassum and rice seed on solid-state fermentation. Jurnal Biologi Indonesia 12 (2): 249-256. [Indonesian]

Kobayasi S, Okazaki N, Koseki T. 1992. Purification and characterization of an antibiotic substance produced from Rhizopus oligosporus IFO 8631. Biosci Biotechnol Biochem 56:94-98.

Kusmiati, Tamat SR, Jusuf E, Istiningsih R. 2007. Beta-glucan production from two strains of Agrobacterium sp in medium containing of molasses and uracil combine. Biodiversitas 8 (1) 123-129.

Kustyawati ME. 2009. Study on the role of yeast in tempe production. J Agritech 29 (2) 64-70.

Kustyawati ME, Sari M, Haryati T. 2013. Effect of Fermentation using Saccharomyces cerevisiae on the biochemical properties tapioca. J Agritech 33 (3): 281-287.

Kustyawati ME, Nawansih O, Nurdjannah S. 2016. Profile of aroma compounds and acceptability of modified tempeh. Int Food Res J 24 (2): 734-740

Lee JN. 2001. Purification of soluble ß-glucan with immuno-enhancing activity from the cell wall of yeast. Biosci Biotechnol Biochem 65 : 837-841.

Many JN, Vizhi K. 2014. Analysis of Different Extraction Methods on the Yield and Recovery of $\beta$-Glucan from Baker's Yeast (Saccharomyces cerevisiae). Int J Innovative Sci Eng Technol 1 (6): 268-271.

Meena DK, Das P, Kumar S, Mandal SC, Prusty AK, Singh SK, Akhtar MS, Behera BK, Kumar K, Pal AK, Mukherjee SC. 2012. Betaglucan: an ideal immunostimulant in aquaculture (a review). Fish Physiol Biochem 39:431-457. DOI 10.1007/s10695-012-9710-5

Melliawati R, Rohmatussolihat, Octavina F. 2006. Selection of potential microorganisms for sago starch fermentation. Biodiverisitas 7 (2): 101-104.

Mo H, Kariluoto S, Piironen V, Zhu Y, Sanders M, Vincken J, WolkersRooijackers JCM, Nout MJ. 2013. Effect of soybean processing on content and bioaccessibility of folate, vitamin B12 and isoflavones in tofu and tempe. Food Chem 141: 2418-2425. DOI:10.1016/j.foodchem.2013.05.017.
Naruemon M, Romanee S, Cheunjit P, Xiao H, McLandsborough LA, Pawadee M. 2013. Influence of additives on Saccharomyces cerevisiae $\beta$-glucan production. Int Food Res J 20 (4): 1953-1959.

Pangastuti A, Alfisah RK, Istiana NI, Sari SLA, Setyaningsih R, Susilowati A, Purwoko Tj. 2019. Metagenomic analysis of microbial community in over-fermented tempeh. Biodirversitas 20 (4): 11061114

Pengkumsri N, Sivamaruthi BS, Sirilun S, Peerajan S, Kesika P, Chaiyasut K, Chaiyasut CT. 2017. Extraction of B-glucan from Saccharomyces cerevisiae: Comparison of different extraction methods and in vivo assessment of immunomodulatory effect in mice. J Food Sci Technol 37 (1): 124-130

Pratiwi LD. 2018. Study of microorganism growth kinetics and $\beta$-glucan content during tempe fermentation with the addition of Saccharomyces cerevisiae. [Thesis]. University of Lampung, Bandar Lampung. [Indonesian]

Rizal S, Kustyawati ME, Murhadi, Hasanudin U, Marniza. 2018. Pengaruh konsentrasi Saccharomyces cerevisiae pada kandungan abu, protein, lemak dan beta-Glucan Tempe. Prosiding Seminar Nasional Fakultas Pertanian UNS 2 (1): 96-103. [Indonesian]

Rizal S, Kustyawati ME, Murhadi, Hasanudin U, Fatimah. 2018b.The Effect of Inoculum Types On The Yeast Growth Pattern During Tempe Fermentation. Proceeding of PATPI-SEAFAST International Conference "Science-Based Ingredients: The Future Food in Asia". October 2018. Jakarta, Indonesia. [Indonesian]

Rehms H, Barz W.1995. Degradation of stachyose, raffinose, melibiose and sucrose by different tempe-producing Rhizopus fungi. Appl Microbiol Biotechnol 44: 47-52.

Saini R, Saini HS, Dahiya A. 2017. Amylases: Characteristics and industrial applications. J Pharmacogn Phytochem 6 (4): 1865-1871.

Setiarto RHB, Widhyastuti N, Saskiawan I. 2016. Effect of lactic acid bacteria, fungi and yeast fermentation on nutritional quality of sorghum flour. Agritech 36 (4): 440-449.

Shokri H, Asadi F, Khosravi AR. 2008. Isolation of B-glucan from the cell wall of Saccharomyces cerevisiae. Nat Prod Res 22 (5): 414-421.

Soka S, Suwanto A, Sajuthi D, Rusmana I. 2014. Impact of tempeh supplementation on gut microbiota composition in Sprague-Dawley rats. Res J Microbiol 9 (4): 189-198.

Sparringa RA, Owens JD. 1999. Protein Utilization during soybean tempeh fermentation. J Agric Food Chem 47: 4375-4378.

Suprihatin. 2010. Teknologi Fermentasi. UNESA Press, Surabaya. [Indonesian]

Thontowi A, Kusmiati, Nuswantara S. 2007. $\beta$-Glucan production of Saccharomyces cerevisiae in medium with different nitrogen sources in air-lift fermentor. Biodiversitas 8 (4): 253-256.

USDA. National Nutrient Data Base for Standard. 2014. Basic Report 20649, Tapioca, pearl, dry. The National Agricultural Library, USA.

Vannucci L, Krizan J, Sima P, Stakheev D, Caja F, Rajsiglova L, Horak V, Saieh M. 2013. Immunostimulatory properties and antitumor activities of glucans. Intl J Oncol 43: 357-364.

Varelas V, Tataridis P, Liouni M, Nerantzis ET. 2016. Application of Different Methods for The Extraction of Yeast B-glucan. e-J Sci Technol (e-JST) 2 (1): 75-81.

Walker GM, Stewart GG. 2016. Review: Saccharomyces cerevisiae in the production of fermented beverages. Beverages 2 (30): 1-12.

Wang HL, Ruttle DI, Hesseltine W. 2012. Protein Quality of Wheat and Soybeans after Rhizopus oligosporus Fermentation. J Nutr 20 (1): 109-114.

Widiantara T, Sutrisno AD, Juliardi. 2013. Processing of modified cassava flour-based on variations in microorganisms types and fermentation time. Infomatek 4 (1): 27-38. [Indonesian]

Widyastuti N, Baruji T, Giarni R, Isnawan H, Wahyudi P, Donawati. 2011. Analysis of beta-glucan content soluble in water and alkali from oyster mushroom (Pleurotus ostreatus) and shiitake (Lentinus edodes) body. Jurnal Sains dan Teknologi 13 (3): 182-191. [Indonesian] 